\title{
The True Lex Mercatoria: Law Beyond the State
}

\author{
Ralf Michaels*
}

\begin{abstract}
Is there an anational lex mercatoria, a "global law without a state?" The debate seems infinite. Some argue that the rules, institutions, and procedures of international arbitration have now achieved a sufficient degree both of autonomy from the state and of legal character that they represent such an anational law. Others respond that whatever law merchant may exist is really state law - dependent on national norms and the freedom of contract they provide, and on the enforceability of arbitral awards by national courts.

This paper suggests that the dichotomy of anational law and state law is false. Although an anational law merchant would be theoretically possible, the true lex mercatoria we are currently observing is not such an anational law. Rather, it is an emerging global commercial law that freely combines elements from national and non-national law. This transnational law presents a far more radical challenge to traditional statebased conceptions of law than the idea of an anational law. It makes the distinction between anational law and state law that permeates the debate over law merchant simply irrelevant by transcending it. The true lex mercatoria marks the shift in global law from segmentary differentiation in different national laws to a functional differentiation. It is a law beyond, not without, the state.
\end{abstract}

\section{The New Romance of the Lex Mercatoria}

In 1923, Wyndham A. Bewes published The Romance of the Law Merchant. ${ }^{1}$ The enchanting title (more than the book itself) evokes the ambivalent situation be-

\footnotetext{
* Professor of Law, Duke University School of Law. Thanks are due to Gralf-Peter Calliess, Gunther Teubner and Peer Zumbansen, as well as participants at the Toronto workshop for debates, and to Carla DePriest, and Catherine Gibson for splendid last-minute research assistance. E-mail: Michaels@law.duke.edu.

1. Wyndham Anstis Bewes, The Romance of the Law Merchant: Being an Introduction to the Study of International and Commercial Law with Some Account of the Commerce and Fairs of the Middle Ages (1923).
}

Indiana Journal of Global Legal Studies Vol. 14 \#2 (Summer 2007)

(C)Indiana University School of Law 
tween fact and fiction that the idea of a lex mercatoria has always held. Lex mercatoria describes both - the reality of an emerging set of legal norms, procedures, and institutions outside the state and its institutions, as well as the romantic ideal of a spontaneous law created in, by, and for commerce, independent from the state.

While the romance is eternal, the conceptions of this lex mercatoria have changed over time. One can distinguish three stages. ${ }^{2}$ The first stage concerns an ancient lex mercatoria in the Middle Ages, a transnational set of norms and procedural principles, established by and for commerce in (relative) autonomy from states. ${ }^{3}$ The second stage describes the renaissance of the idea as a "new lex mercatoria" in the $20^{\text {th }}$ century, an informal and flexible net of rules and arbitrators establishing a private international commercial law. ${ }^{4}$ Finally, a third stage has been described as a "new new lex mercatoria," which moves from an amorphous and flexible soft law to an established system of law with codified legal rules (first and foremost the UNIDROIT Principles of International and Commercial $\mathrm{Law}^{5}$ ) and strongly institutionalized court-like international arbitration. ${ }^{6}$

For some time, positions on the question of whether an anational law merchant existed or exists were matters of faith rather than of academic rigor, and some participants in the debate seemed driven more by the wish to defend their own fields than by a disinterested search for adequate theories. Scholars and especially practitioners in commercial and arbitration law promoted lex mercatoria not least because their fields seemed to benefit from it. ${ }^{7}$ Scholars of conflict of laws, by contrast, ab-

2. For a discussion on the use of history in debates about the current lex mercatoria, see Nikitas Hatzimihail, The Many Lives_And Faces_of Lex Mercatoria: An Essay on the Genealogy of International Business Law 71 Law \& Contemp. Probs. (forthcoming Summer 2008).

3. Harold J. Berman, Law and Revolution: The Formation of the Western Legal Tradition 332-56 (1983) (discussing the rise of mercantile law); see also Lex Mercatoria and Legal Pluralism: A Late Thirteenth-Century Treatise and Its Afterlife (Mary Elizabeth Basile et al. eds., 1998) [hereinafter Lex Mercatoria and Legal Pluralism] (providing an overview of the concept's history).

4. See generally JH Dalhuisen, Legal Orders and Their Manifestation: The Operation of the International Commercial and Financial Legal Order and Its Lex Mercatoria, 24 Berkeley J. Int'L L. 129 (2006) (discussing the emergence of the new lex mercatoria).

5. International Institute for the Unification of Private Law (UNidroit), UNiDROIT Principles of International Commercial Contracts (2004 ed.).

6. See generally L. Yves Fortier, The New, New Lex Mercatoria, or, Back to the Future, 17 Arb. INT'L 121 (2001) (describing the emergence of the new, new lex mercatoria).

7. See Yves Dezalay \& Bryant G. Garth, Dealing in Virtue: International Commercial Arbitration and the Construction of a Transnational Legal Order 3-17 (1996); Filip De Ly, Lex Mercatoria (New Law Merchant): Globalisation and International Self-Regulation, in RuLES AND Networks: The Legal Culture of Global Business Transactions 159, 180 (Richard P. Appel- 
horred the idea of a non-state law demanding recognition, not least because they feared for central tenets of their field. Empirical issues mattered surprisingly little in this debate. When Lord Mustill wrote his seminal critical article on lex mercatoria, ${ }^{8}$ he rested much of his criticism on the paucity of actual substance of the alleged lex mercatoria notwithstanding, proponents of lex mercatoria used these twenty principles precisely to prove their point that a lex mercatoria actually exists-which suggests, among other things, that they themselves had never felt it necessary to provide the same kind of in-depth empirical research. ${ }^{.1}$ Old, new, or new new-whether there ever was a true lex mercatoria in the sense of a law created and administered by commerce itself and autonomous from the state-was long relatively secondary.

That these discussions are not resolved suggests that they concern matters not so much of empirical facts but of perspective, of theory. The main issue is not the existence of a lex mercatoria, in the past or in the present. It is the theoretical possibility of a law merchant, and whether it can be considered to be law. Indeed, while the reality of lex mercatoria is still in dispute, its theories have become more sophisticated. The most promising one comes from systems theory and the theory of autopoiesis. Gunther Teubner, in his seminal article on a global Bukowina, ${ }^{12}$ dismisses both sides of the current debate on a law without a state as theoretically inadequate. Proponents of a law merchant as based entirely on contract without any legal orderthe French concept of the "contrat sans loi" — ignore that a contract cannot be binding without a legal system that makes it so. Opponents of a law without a state, on the other hand, emphasize a primordial position for the sovereign nation-state that has become questionable in a globalized view of the world. Teubner's own ingenious conception starts from the idea of a contrat sans loi that he has just dismissed, and develops it further in an important way. The contract is not binding in and by itself,

baum, William L.F. Felstiner \& Volkmar Gessner eds., 2001) [hereinafter Rules and Networks].

8. The Rt. Hon. Lord Justice Michael Mustill, The New Lex Mercatoria: The First Twenty-five Years, 4 Аrb. Int'L 86 (1988).

9. $I d$. at 114 ("This list, incomplete as it may be, seems rather a modest haul for 25 years of international arbitration.”).

10. Id. at $110-14$.

11. This has changed for the "new new" lex mercatoria. The most impressive list of rules of lex mercatoria is the Transnational Law Digest \& Bibliography (TLDB), which is compiled on a continuous basis by the Center for Transnational Law (CENTRAL) at the University of Cologne, under the guidance of Prof. Klaus Peter Berger. It is available at http://tldb.uni-koeln.de/.

12. Gunther Teubner, "Global Bukowina": Legal Pluralism in the World Society, in Global Law Without a State 3 (Gunther Teubner ed., 1997). 
but neither does it require an outside (state-based) legal order to be binding. Rather, the contract itself creates its own legal order, because it contains an internal hierarchy: it combines primary norms on the specifically contractual rights and obligations and secondary norms giving these primary norms their validity. The contract temporalizes itself by placing itself between the past of standard terms to which it refers and the future of adjudication. And the contract externalizes, by means of a (contractual!) arbitration agreement, the adjudication and enforcement of the agreement. A whole legal system, including objective law and adjudication, emerges from, and in return applies to, the mere contracts.

The traditional model of the contrat sans loi could at best explain only how each individual commercial contract can create its own anational legal order, not how the sum of these contracts gets combined into an order worthy of the name lex mercatoria. Teubner, in contrast, bases his concept not on the individual contract, but on contract as institution. In another article, ${ }^{13}$ he explores this aspect in some more detail: because the externalization of adjudication typically goes not to an ad hoc arbitrator but to an institutionalized system of arbitration dealing with many contracts, an "official" legal order emerges which thereby is able to transcend these individual contracts on which it is based. Law merchant creates and perpetuates itself as an autonomous legal system without a state. Lex mercatoria thus becomes a legal regime independent from, but parallel to, the traditional legal regimes of national legal orders. ${ }^{14}$ Since this regime would be illegitimate without a constitution, it needs to constitutionalize itself. ${ }^{15}$

The model has been very influential; it has breathed life into the theoretical debate on lex mercatoria that had otherwise become somewhat sterile. Other authors have refined the systems theoretical view of lex mercatoria-by applying it to choice of law, ${ }^{16}$ by looking more closely at its "reflexive" character, ${ }^{17}$ and by posi-

13. Gunther Teubner, Review Essay, Breaking Frames: The Global Interplay of Legal and Social Systems, 45 Ам. J. Сомp. L. 149, 162-65 (1997) [hereinafter Breaking Frames]; see also Gunther Teubner, Breaking Frames: Economic Globalization and the Emergence of Lex Mercatoria, 5 Eur. J. Soc. Theory 199, 211-13 (2002) (a republication of Breaking Frames with slight modifications).

14. See Andreas Fischer-Lescano \& Gunther Teubner, Regime-Collisions: The Vain Search for Legal Unity in the Fragmentation of Global Law, 25 Mich. J. INT'L L. 999, 1009-12 (discussing private legal regimes and their relation to the global legal system).

15. Id. at $1014-17$.

16. Gabriele Scherer, Das internationale Privatrecht als globales System (Feb. 15, 2005) (unpublished Ph.D. dissertation, Humboldt University, http://edoc.hu-berlin.de/docviews/abstract. php?. lang=ger\&id $=26355$ ).

17. Gralf-Peter Calliess, Reflexive Transnational Law: The Privatisation of Civil Law and the Civilisation of Private Law, 23 Zeitschrift für Rechtssoziologie 185 (2002), available at http:// 
tioning it in relation both to the political system ${ }^{18}$ and the economic system. ${ }^{19}$ Furthermore, the conceptualization of lex mercatoria as an autonomous legal system parallel to that of states has led scholars to move from conceptualization issues to issues of legitimacy: scholars seek responses to the traditional criticism that lex mercatoria, as purely "private" law, lacks democratic legitimacy and constitutional constraints. ${ }^{20}$ They do so, frequently, by positing that the new lex mercatoria is developing its own constitutionalization outside the state. ${ }^{21}$

Systems theory provides excellent tools for the analysis of law's globalization, and while the arguments that follow are not strict applications of systems theory, their heritage to it should become clear. Indeed, in many ways the argument presented here builds on systems theory in general and Teubner's article in particular, and many of the ideas here proposed may, at first sight, seem to present mere clarifications of his theory. However, these clarifications are important, because many of the results that have been reached on the basis of his theory (more perhaps by students of Teubner's text than by himself) are unconvincing, both empirically and theoretically. Section II shows that a lex mercatoria as a truly anational legal system, though theoretically possible, has never existed - neither in the Middle Ages, nor in the $20^{\text {th }}$ century as "new lex mercatoria," nor today as "new new lex mercatoria." At all times, the transnational law of commerce included both state and non-state norms and institutions. Section III shows why an anational law merchant is actually implausible from the perspective of systems theory. From the perspective of the state (representing the political system), there

ssrn.com/abstract $=531063$.

18. Mathias Albert, Zur Politik der Weltgesellschaft: Identität und Recht im Kontext internationaler Vergesellschaftung 235-70 (2002).

19. Tanja Lieckweg, Das Recht der Weltgesellschaft. Systemtheoretische Perspektiven auf die Globalisierung des Rechts am Beispiel der lex mercatoria (2003).

20. For such a criticism directed at Teubner's concept, see Brigitta Lurger, Der Pluralismus der "lex mercatoria“. Anmerkungen zu einem Aufsatz von Gunther Teubner, 16 Rechtshistorisches J. 705 (1997). For a political reconceptualization under an approach closely related to that of systems theory, see Peer Zumbansen, Piercing the Legal Veil: Commercial Arbitration and Transnational Law, 8 Eur. L.J. 400, 418-21 (2002).

21. See, e.g., Gunther Teubner, Global Private Regimes: Neo-Spontaneous Law and Dual Constitution of Autonomous Sectors?, in Public Governance in the Age of Globalization 71 (KarlHeinz Ladeur ed., 2004) (arguing that globalization enables the law to help create a dual constitution of autonomous sectors of world society); Gunther Teubner, Societal Constitutionalism: Alternatives to State-Centred Constitutional Theory?, in Transnational Governance and Constitutionalism 3 (Christian Joerges et al. eds., 2004) (discussing how constitutional theory should respond to challenges related to the inclusion/exclusion problem); Zumbansen, supra note 20 (discussing new forms of international governance including constitutionalization). 
are good reasons why law outside the state, other than law of other states, is not recognized as law. From the perspective of commerce (representing the economic system), the distinction between state and non-state is simply irrelevant; what matters is which laws and institutions are more efficient, regardless of their source. Section IV provides an explanation. Authors endorsing the anational, or nonstatal, character of lex mercatoria, I argue, are barking up the wrong tree. In perpetuating the state/non-state dichotomy, the lex mercatoria without a state remains within a state-focused legal paradigm. This is inconsistent with the emphasis of systems theory on a world society that is differentiated along functional subsystems rather than along states. ${ }^{22} \mathrm{~A}$ functional analysis should reveal a global commercial law that reflects the economic system, and should transcend boundaries between state and non-state. The article concludes with some implications for the theory of lex mercatoria and for global law in general.

\section{EMPIRICAL INADEQUACY}

Teubner suggests that "the 'global reach' of law [and the existence of an anational law merchant] is no longer treated as a question of doctrinal definition but as an empirical question which allows for variation." ${ }^{23}$ Indeed, law merchant proponents have long argued that they have reality on their side, and they have criticized their opponents for ignoring reality in order to protect their theories. There is, they point out, a real law merchant outside the state. If traditional, state-oriented theories of law are unable to capture this reality, then these theories are proven to be inadequate.

This turn to empiricism is risky. Law merchant proponents themselves claim a

22. One might object that I make too much of a mere terminological difference, given that the "private" law described in the work of many proponents of "new new lex mercatoria" actually combines national, international, and non-national law. Even if the difference were merely terminological, though, speaking of "law without a state" still would conjure an image of lex mercatoria that is both substantively and theoretically inadequate. As regards substance, most authors in describing lex mercatoria focus almost exclusively on those of its parts that are in opposition to state law. As regards theory, the concept of a law outside or without a state is significantly different from that of a law beyond the state, as I show in this article. It seems plausible that both the theoretical and the substantive inaccuracies are consequences that flow from the concept of an anational law. Thus, while the concept here proposed of "law beyond the state" may merely make the discourse more accurate, it should thereby be useful in creating a more adequate image of lex mercatoria. In the end the main goal of this paper is not to criticize the work of others, but to suggest a conceptualization in tune with the requirements of empirical findings and of theory.

23. Teubner, supra note 12 , at 11. 
reality whose existence they have a hard time proving. While there is undoubtedly some law outside the state, in all likelihood, a truly anational law merchant does not, nor did it ever, exist. Law merchant proponents commit exactly the mistake for which they criticize their opponents: they construct reality to make it fit their theories.

This is no radical suggestion. In fact, the non-existence of a truly autonomous law merchant is by now so widely known that it may suffice here to sum up the rich findings by others on this question.

\section{A. The Medieval Lex Mercatoria}

This is the case for the alleged medieval lex mercatoria. Recent studies by legal historians have made quite clear that the existence of a lex mercatoria, at least as a legal system that was internally uniform and externally autonomous from the state, is quite doubtful. Merchants at the fairs of St. Ives, previously named as one creator of law merchant, were governed largely by local official laws. ${ }^{24}$ Dutch and Belgian merchants in the middle ages and early modern times, far from relying exclusively on arbitration and ad hoc quasi-private tribunals, rather used a mixture of private and public legal institutions. ${ }^{25}$ Several more general analyses make the thesis of a historical autonomous non-state lex mercatoria relatively implausible. ${ }^{26}$

In fact, even the historical sources proclaiming a lex mercatoria are ambivalent as to its relation to the state. The earliest known text on lex mercatoria, the Little Red Book of Bristol (ca. 1280), argues that "[m]ercantile law is thought to come from the market," ${ }^{27}$ but later points out, seemingly paradoxically, that "the common law ... is the mother of mercantile law." ${ }^{28}$ Some four hundred years later, the author

24. Stephen E. Sachs, From St. Ives to Cyberspace: The Modern Distortion of the Medieval "Law Merchant,” 21 Am. U. Int'L L. Rev. 685, 687-95 (2006) (despite reference to cyberspace in the title, the article is devoted almost entirely to legal history).

25. Oscar Gelderblom, The Resolution of Commercial Conflicts in Bruges, Antwerp, and Amsterdam, 1250-1650, at 36 (Econ. and Soc'y of the Low Countries, Working Paper No. 2005-2, 2005), available at http://www.lowcountries.nl/workingpapers.html.

26. See, e.g., Oliver Volckart \& Antje Mangels, Are the Roots of the Modern Lex Mercatoria Really Medieval?, 65 S. Econ. J. 427, 446-47 (1999); Albrecht Cordes, The Search for a Medieval Lex Mercatoria, Oxford U. Comp. L.F. 5 (2003), http://ouclf.iuscomp.org/articles/cordes.shtml, text after notes 11-13; Charles Donahue, Jr., Medieval and Early Modern Lex Mercatoria: An Attempt at the Probatio Diabolica, 5 Chi. J. Int'L L. 21, 27-29 (2004).

27. "Lex mercatoria a mercato provenire sentitur et inde primo sciendum est ubi mercatum se tenet de quo huiusmodi leges proveniunt," Quoted in Lex Mercatoria and Legal Pluralism, supra note 3 , at 1 . What exactly is meant by mercatum is not clear. See editors' comments, $i d$.

28. "[L]ex communis que est mater legis mercatorie." Id. at 18. Accord Donahue, supra note 26, at $26-27$. 
of perhaps the most famous book in English on lex mercatoria, Gerard Malynes, is equally ambivalent. Although he emphasizes that lex mercatoria is "not a Law established by the Soveraigntie of any Prince," the sovereign seems far from irrelevant, since in the same sentence Malynes makes clear that "it is a Customary Law approved by the authoritie of all Kingdomes and Commonweales." ${ }^{29}$ Finally, Stracca's De Mercatura, often named as an exposition of lex mercatoria, actually deals rather with ius commune and thus applies to commerce a law that is known to combine official laws with the received ratio scripta of Roman law. ${ }^{30}$ To all these authors, the communion of a law of the market and a law of the state may not have appeared paradoxical. Lex mercatoria, like ius gentium and general principles of law, was like the law of all states and therefore the law of no state in particular; ${ }^{31}$ a law without a particular state, but not a law thereby detached from states at large.

This is not to say that a lex mercatoria did not exist. Both the name and the concept were well-known. But this lex mercatoria was not autonomous from official law. Lex mercatoria was a mixture of official laws and established mercantile customs and institutions, of official courts and quasi-private local tribunals: "bundles of public privileges and private practices, public statutes and private customs sheltered under the umbrella concept of merchant law by their association with a particular sort of supra-local trade and the people who carried it out." ${ }^{32}$ Lex mercatoria was not non-state law-it was an amalgam of state and non-state rules and procedures, kept together by its subject: the merchants.

\section{B. The New Lex Mercatoria}

The rise of the state came hand in hand with the decline of lex mercatoria. The state occupied the realm of commercial law and in the process incorporated or replaced many of the rules created in commerce, with the consequence that a

29. Gerard Malynes, Consuetudo vel Lex Mercatoria, or the Ancient law-merchant, at Foreword (London 1622).

30. Charles Donahue, Jr., Benvenuto Stracca's De Mercatura: Was There a Lex Mercatoria in Sixteenth-Century Italy?, in From Lex Mercatoria to Commercial Law 69, 74-78 (Vito Piergiovanni ed., 2005). For a summary of the argument, see Donahue, supra note 26, at 31-34.

31. The same paradoxical step underlies the medieval adage vox populi vox dei: if all agree on something, then its truth transcends the individuals who agree. See S.A. Gallacher, Vox Populi, Vox Dei, 24 Phil. Q. 12, 13 (1945).

32. Emily Kadens, Order Within Law, Variety Within Custom: The Character of the Medieval Merchant Law, 5 Chi. J. Int'L L. 39, 42 (2004). 
non-state lex mercatoria was unable to compete. ${ }^{33}$ In return, the relative decline of the state and the rise of transnational commerce in the $20^{\text {th }}$ century are invoked as reasons for its renaissance as a new lex mercatoria.

Proponents painted a picture of lex mercatoria as an autonomous law of global commerce that fulfills the same functions as the law of the state. Arbitral tribunals took over the task of adjudication. The task of law-making fell largely to commerce itself, whose customs were viewed as law. The enforcement of ensuing decisions presented a problem, as long as the state held the monopoly on violence. But proponents pointed to functional equivalents to state enforcement, such as reputational pressure or money held in escrow to ensure enforcement.

It is especially important to see the relation of this proclaimed new lex mercatoria to the state's law. Despite functional equivalence, the advantage of international arbitration over national courts and of lex mercatoria over state law was traditionally seen to reside in their essential otherness. Where state law relied on formalistic and abstract legal rules, arbitration offered the attraction of decisions based on equity, tailored to the specific requirements, unbound by a system of binding statute or precedent. Where state courts relied on legal experts with little expertise on the specific requirements of commerce, arbitrators were themselves merchants who knew about such requirements. Where opinions in state courts were published, arbitral decisions provided parties with much-needed privacy and secrecy. Where in state courts public norms trumped the will of the parties, arbitrators considered only the private interests of the parties before them. Political influence on the law, thought to be detrimental in state law, was notably absent.

Whether this new lex mercatoria really represents an anational system of law, and how important it is in fact, have of course always been disputed. ${ }^{34}$ One problem, frequently discussed though relatively secondary, is whether all of this can be referred to as "law." Teubner's combination of social and juridical validity tends to confound different criteria of valid law, ${ }^{35}$ and the frequent emphasis by arbitrators

33. Although some argue that the common law incorporated the pre-existing lex mercatoria, evidence seems to suggest it side-stepped any lex mercatoria and drew directly on existing customs and usages. See, e.g., J.H. Baker, The Law Merchant and the Common Law Before 1700, 38 CAмBRIDGE L.J. 295, 296-97 (1979) (discussing how courts held that custom created legal duties at common law in assumpsit actions).

34. For a very useful overview of different aspects of this debate, see Klaus Peter Berger, The Creeping Codification of the Lex Mercatoria 32-113 (1999).

35. See Ralf Michaels, The Re-state-ment of Non-State Law: The State, Choice of Law, and the Challenge from Global Legal Pluralism, 51 Wayne L. Rev. 1209, 1238 (2005). For a discussion on the distinction between sociological and juridical concepts of law, see Robert Alexy, The Argument from Injustice: A Reply to Legal Positivism 85-88 (Bonnie Litschewski Paulson \& Stanley L. 
that equity and customs rather than law should govern their decisions strengthens this suspicion. ${ }^{36}$ References in arbitral decisions to "lex mercatoria" or "law merchant" as applicable law are far less frequent than scholars sometimes believe. ${ }^{37}$ Moreover, the mere reference does not create a full-fledged legal system, even under a constructivist theory..$^{38}$

These are largely matters of semantics. More important are questions as to the systemic, complete character of the "new lex mercatoria," especially its autopoietic structure..$^{39}$ As long as most arbitral decisions remained unpublished and no strong system of precedent existed, each arbitrator had to either import legal norms from state law or translate social customs from commerce into ad hoc applicable legal norms. A continuous and evolving system of law could not develop in this way. Each arbitrator had to seek his norms anew, either from the facts of commercial customs or from the norms of state and international law; a non-national lex mercatoria was not available.

\section{The New New Lex Mercatoria}

There is a claim that this has changed and that a "new new lex mercatoria" has finally led to a system that is autonomous and sufficiently legalized to constitute an anational legal system comparable to the legal systems of states. ${ }^{40}$ This new new lex mercatoria resembles the new lex mercatoria in that it is still presented as functionally equivalent to state law. However, its image has completely shifted. Where the

Paulson trans. 2002) (1994); François Ost \& Michel van de Kerchove, De la pyramide au réSeau? Pour une theorie dialectique du droit 324-38 (2002).

36. In the language of systems theory, many arbitral decisions do not apply the code legal/illegal, which is central to a legal system.

37. Felix Dasser, Lex Mercatoria-Critical Comments on a Tricky Topic, in Rules and Networks, supra note 7, at 189, 191-97. However, wider use (or at least knowledge) of lex mercatoria has been reported elsewhere. E.g., Klaus Peter Berger, Holger Dubberstein, Sascha Lehmann \& Victoria Petzold, The CENTRAL Enquiry on the Use of Transnational Law in International Contract Law and Arbitration: Background, Procedure and Selected Results, in The Practice of Transnational Law 91, 103-04 (Klaus Peter Berger ed., 2001).

38. See Calliess, supra note 17 , at 194.

39. See the debate in Berger, supra note 34, 89-102.

40. See, e.g., id. at 141-227 (discussing the "creeping codification" of the lex mercatoria through the drafting of open-ended principles and rules); Fortier, supra note 6, at 124-27 (explaining how unifying the sources of transnational law into defined principles and rules can overcome the problem of the lex mercatoria not being practical enough to use in legal practice). For a systems theory perspective discussing the conditions under which the lex mercatoria could emerge as an autonomous legal system, see Calliess, supra note 17, at 193-201. 
attraction of the older new lex mercatoria lay in its essential otherness compared with state law, the attraction of the new new lex mercatoria lies in its similarity to state law. More and more, international arbitration has been legalized; amorphous equity has yielded to detailed legal rules. So-called “formulating agencies" lay down positive rules of lex mercatoria; the UNIDROIT Principles are presented as a fullfledged codification of lex mercatoria. ${ }^{41}$ International arbitrators are now expected to consider national mandatory state norms to ensure enforceability and to enhance the legitimacy of their position, or even to develop an independent body of transnational mandatory norms. Arbitrators are no longer merchants; they are experts in international commercial law. More and more arbitral awards are published, enabling a system of precedent. In other words, the new new lex mercatoria now looks like state law, only better. The most important resemblance it bears to its earlier version is that the new new lex mercatoria is still portrayed as a law without political influence. This looks like a global re-inauguration of the emancipation within the state law of private commercial law from politics.

If such a lex mercatoria existed, it could indeed constitute a global law without a state. That it is law seems clear. More problematic is the claim for independence from national laws. Some view the system of international arbitration as progressing toward autonomy. ${ }^{42}$ Some point out that the UNIDROIT Principles go beyond their basis in party autonomy ${ }^{43}$ and are now almost fully independent of national laws. They do not address all areas of the law. Lex mercatoria does draw a distinction between norms within and norms outside the system. But this distinction does not go along state lines. It goes along functional lines, depending on whether norms are adequate for international commerce or not. ${ }^{44}$ Consumer law, constitutional law - all these functionally separate bodies of law need not form part of lex mercatoria. At least in the form of the UNIDROIT Principles,

41. Ana M. López Rodríguez, Lex Mercatoria and Harmonization of Contract Law in THE EU 145-46 (2003); Gesa Baron, Do the UNIDROIT Principles of International Commercial Contracts Form a New Lex Mercatoria?, 15 Аrв. INT'L. 115, 124-25 (1999).

42. E.g., Julian D.M. Lew, Achieving the Dream: Autonomous Arbitration, 22 Arв. Int'L. 179, 181 (2006); see also Reza Banakar, Reflexive Legitimacy in International Arbitration, in EMERging LegaL Certainty: Empirical Studies on the Globalization of Law 347, 348-50 (Volkmar Gessner \& Ali Cem Budak eds., 1998) [hereinafter Emerging Legal Certainty] (arguing from a systems theory perspective).

43. Michael Joachim Bonell, An International Restatement of Contract Law: The UNiDROIT Principles of International Commercial Contracts $80-82$ (3d ed. 2005).

44. See id. at 47. Whether the distinction is successful is another matter; for some doubts, see Isabelle Veillard, The General and Commercial Character of the UNIDROIT Principles of International Commercial Contracts, 2007 Int'L Bus. Law J. 479 (2007). 
the new new lex mercatoria is gaining some recognition as a legal system without a state. ${ }^{45}$ For example, a recent draft for a European Regulation on the law applicable to contractual obligations provided for the choice of the UNIDROIT Principles as applicable law. ${ }^{46}$ More important perhaps are arguments that lex mercatoria is now going beyond its traditional focus on contract enforcement and is building its own constitutional law, so necessary for a full-fledged legal system. ${ }^{47}$

However, such a legal system is not in existence, and whether it ever will be seems doubtful. Autonomous international arbitration is still very much a "dream." In reality, arbitration faces difficulties in achieving the legitimacy assigned to state courts, $^{49}$ and remains firmly interdependent with domestic courts. ${ }^{50}$ The UNIDROIT Principles contain an important opening clause for domestic and supranational mandatory norms in Article 1.4. The most recent version of the Rome I Regulation proposal has eliminated the possibility of choosing non-state law as the applicable law..$^{51}$ Arbitrators may make frequent use of the UNIDROIT Principles, but usually only as one of many bodies of legal rules to which they look for guidance. All of this suggests that this new new lex mercatoria is not a self-sufficient legal system independent from the state..$^{52}$ National laws are legal systems because

45. For a more detailed analysis, see Ralf Michaels \& Mathias Scherer, Preamble (Function of the Principles), in Commentary on the UNIDROIT Principles of International Commercial Contracts (2004) (Stefan Vogenauer \& Jan Kleinheisterkamp eds., forthcoming).

46. Commission Proposal for a Regulation of the European Parliament and the Council on the Law Applicable to Contractual Obligations (Rome I), at 5, COM (2005) 650 final (Dec. 15, 2005).

47. Teubner, Global Private Regimes, supra note 21, at 75-82; Zumbansen, supra note 20, at 42728, 431-32.

48. See Lew, supra note 42, at 179.

49. Charles N. Brower, Charles H. Brower, II \& Jeremy K. Sharpe, The Coming Crisis in the Global Adjudication System, 19 Arв. InT'L. 415, 418 (2003) ("[E]lements and perceptions of legitimacy are too often spectacularly absent.”).

50. Ralf Michaels, Retour aux sources? Droit et politiques des sources du droit contemporain aux Etats-Unis [Back to the Sources? Law and Politics of Sources of Contemporary American Law], in Les Sources Du Droit: Aspects Contemporains (Société de législation comparée ed. 2007).

51. Position of the European Parliament adopted at first reading on 29 December 2007 with a view to the adoption of Regulation (EC) No .../2007 of the European Parliament and of the Council on the law applicable to contractual obligations (Rome I), Consideration 15 (allowing for incorporation by reference only), available at http://www.europa.edu/sides/getDoc.do? type=TA\&reference $=$ P6-TA-2007-0560\&language $=\mathrm{EN} \&$ ring $=$ A6-2007-0540\#BKMD-18.

52. Another argument by critics has less force. Many critics emphasize that lex mercatoria is not independent of the state because arbitral awards ultimately require enforcement by state courts. But the same is true for state judgments that frequently need to be enforced in another country, and nobody would argue that these legal systems are for that reason not independent of each other. 
they create a clear distinction between domestic law and foreign law. ${ }^{53}$ While domestic law is always applicable, foreign law is applicable only if referred to by domestic choice of law rules. ${ }^{54}$ The current U.S. debate over the use of comparative law in constitutional interpretation clearly shows the importance of this distinction. ${ }^{55} \mathrm{Al}-$ though gaps in the legal system could be filled by incorporating foreign norms, in reality this rarely happens. By contrast, the new new lex mercatoria makes no distinction similar to that between domestic and foreign law, which would translate into the distinction between non-state law and state law. If law merchant were an autonomous anational law, the use of state law would require some sort of reception process. State norms would have to be incorporated or their applicability would have to be justified through other specific mechanisms. Gaps could be filled from within lex mercatoria without the need to refer to the "foreign" law of states. ${ }^{56}$ But this is not the case: arbitral awards and court decisions, autonomous law merchant norms, and domestic laws from various states are cited and used in decisions with no obvious hierarchical distinction.

That the new new lex mercatoria is not autonomous from the state but rather contains both state and non-state norms and institutions becomes even clearer if we view it from the perspective of international commerce itself. Here, it is obvious that the law of international commerce is not limited to law without a state. Rather, market participants choose freely between state courts and arbitrators as adjudicators, and between state norms and non-state norms as applicable norms. Frequently, arbitration is considered more efficient; sometimes (though far less frequently than is often alleged), non-state law like lex mercatoria, general principles of law, or the UNIDROIT Principles are preferred over state law. But to a considerable degree, parties rely on the state and its institutions. For example, British reinsurers are reported to prefer courts over arbitration, ${ }^{57}$ and Japanese fishermen at the harbor of Tokyo prefer the state-sponsored Tuna Court over private arbitration..$^{58}$ Attorneys advise clients to choose the law of a state over the lex

53. I plan to elaborate this point more fully in a separate article.

54. See Niklas Luhmann, Law as a Social System 481 (Fatima Kastner et al. eds., Klaus A. Ziegert trans., 2004); Calliess, supra note 17, at 214-15.

55. See Michaels, supra note 50, for further references.

56. See Bonell, supra note 43, at 82-86; Emmanuel Gaillard, Transnational Law: A Legal System or a Method of Decision Making?, 17 АRв. INT'L. 59, 61 (2001).

57. Christine Stammel, Back to the Courtroom? Developments in the London Reinsurance Market, in Emerging Legal Certainty, supra note 42, at 61, 88.

58. Eric A. Feldman, The Tuna Court: Law and Norms in the World's Premier Fish Market, 94 Cal. L. Rev. 313, 361 (2006). 
mercatoria, even in its codified form of the UNIDROIT Principles. In reality, even the new new lex mercatoria without a state remains a dream-a theoretical possibility for the future, not a reality for the present.

\section{Theoretical InadeQuacy}

Proponents of commercial law without a state have rightly accused their critics of ignoring reality in order to save their theory. They are correct. There now exists a considerable body of legal rules and adjudicatory proceedings outside the state that presents a challenge for state-based conceptions of law. However, the proponents commit the same mistake if they postulate the existence of an autonomous lex mercatoria because it fits their theories so well. Such a "law without a state" would indeed be theoretically possible. After all, there was law long before we could speak of a state in the modern sense..$^{59}$ But an adequate theory of lex mercatoria cannot rely on theoretical possibilities; it must explain the empirical findings and it must explain why a commercial law based in commerce has not been able to become autonomous. Surprisingly, the systems theoretical approach itself makes the existence of a law without a state implausible. This can be shown through two perspectives - that of the state, representing the political system, and that of international commerce, representing the economic system.

\section{A. The View from the State 60}

The existence of legal norms and institutions outside the state makes a statebased theory of law untenable as an objective, neutral theory of law. But such a theory remains important as a theory formulated from a specific perspective, namely that of the state (or, to be more exact, that of the state's legal system). From

59. Nils Jansen \& Ralf Michaels, Private Law and the State: Comparative Perceptions and Historical Observations, 71 Rabels Zeitschrift für ausländisches und internationales Privatrecht 345 (2007); Charles Donahue, Jr., Private Law Without the State and During its Formation, Ам. J. Cомp. L. (forthcoming). Proponents of law merchant like to point to history to make this point. However, the fact that law without a state was possible in a world without states has few direct implications for a world with states. See Simon Roberts, After Government? On Representing Law Without the State, 68 Mod. L. Rev. 1, 5-11 (2005).

60. For elaboration on this argument, see Michaels, supra note 35, at 1227-38. 
a neutral perspective, there are all kinds of laws, both state-based and non-state based. From the perspective of the state, by contrast, all law is state-based. ${ }^{61}$

Of course this does not mean that the state could ignore non-state law. It does not ignore non-state law, but it treats it in a special way: it "re-states" these norms by translating or even transposing them into the semantics of its own system. One such mode is incorporation: the copying of non-state norms into state-based norms, for example, in the form of a commercial code. A second mode is deference: the transformation of non-state laws into facts, for example, by treating law merchant as customs. A third mode is delegation: the transformation of non-state law into subordinated law, for example, by allowing commerce, in the form of contract autonomy, a space for the development of autonomous norms - norms that achieve their validity, from the state's perspective, only because and insofar as the state recognizes them as such.

Nor does a state-based concept of law mean that an anational law merchant could not possibly be viewed as law. In a sense, from the perspective of each particular state, the law of other states is as foreign (and in need of recognition) as any anational law would be. ${ }^{2}$ In a state-based theory, as implemented in domestic conflict of laws rules, English law is "law" in Germany only because German law recognizes it as such; the same is true for German law in England. The basis for this mutual recognition is not some metaphysical concept of "law" or "state," but simply a system of comity that states grant each other. ${ }^{63}$

In theory, states could extend such comity to lex mercatoria.$^{64}$ After all, the new new lex mercatoria as presented by its proponents does look very much like state law. In reality, they do not: commercial law is domestic law or foreign law (or international law), but not non-state law. From the state's perspective, the restric-

61. My position is misunderstood as a universalist one in Marc Amstutz \& Vaios Karavas, Rechtsmutation: Zur Genese und Evolution des Rechts im transnationalen Raum, 8 Rechtsgeschichte 14, 14-15 (2006).

62. For a similar point, see Boris Schinkels, Die (Un-)zulässigeit einer kollisionsrechtlichen Wahl der UNIDROIT Principles nach Rom I: Wirklich nur eine Frage der Rechtspolitik?, 4 ZEITschrifT für Gemeinschaftsprivatrecht 106, 108 (2007).

63. Comity understood as a reason for rules (of choice of law), not as their substitute. The actual use of comity in doctrine is highly problematic. See Joel Paul, The Transformation of International Comity, 71/3 Law \& Contemp. Probs. (forthcoming).

64. Albert, supra note 18, at 255 (citing Bernd von Hoffmann, Internationally Mandatory Rules of Law Before Arbitral Tribunals, in Acts of State and Arbitration 3, 25 (Karl-Heinz Böckstiegel ed., 1997)). 
tion to state law makes perfect sense. ${ }^{65}$ States maintain their external stability and autonomy through mutual recognition; the state's monopoly of violence can be maintained as long as states assist each other in their enforcement against private actors. Similarly, the legal systems of states maintain their autonomy in a globalizing and interdependent world precisely through mutual recognition and collective allocation of regulatory powers among them. Thus, while the recognition of foreign laws enhances the role of any state's law, because it creates a cartel of lawmakers, this cartel is almost necessarily hostile to outsiders.

So how can we explain the fact that states are becoming somewhat more open to lex mercatoria? Mathias Albert presents the following reason: The official law can safely recognize law merchant, if in other ways than through comity, because lex mercatoria is essentially different - it does not compete for claims of sovereignty. ${ }^{66}$ The flipside may be true as well: The draft Rome Regulation shows that states can also recognize lex mercatoria when and because it is similar to state law in essential ways. However, such recognition presents a greater risk for lex mercatoria than for the state. It means that law merchant must almost necessarily lose the specificities that may have given it whatever functional advantages it has had over state-based law. This is why Lisa Bernstein is so opposed to the incorporation of customs into the UCC, ${ }^{67}$ and why Celia Wasserstein Fassberg deems the recent attempts at codifying lex mercatoria as a step toward its decline. ${ }^{68}$ As long as lex mercatoria is essentially different from state law, it can play an important role. Once it claims to be essentially similar, it suffers a competitive disadvantage.

\section{B. The View from International Commerce}

All law is state law only from the perspective of the state. From the perspective of international commerce, the answer is different but not more helpful for proponents of law without a state. Whether law is state law or not is simply irrele-

65. Contra Schinkels, supra note 62, at 108-11 (arguing that non-application of the UNIDROIT Principles amounts to unconstitutional discrimination).

66. Albert, supra note 18, at 257.

67. Lisa Bernstein, Merchant Law in a Merchant Court: Rethinking the Code's Search for Immanent Business Norms, 144 U. PA. L. Rev. 1765, 1766-69 (1996); Lisa Bernstein, The Questionable Empirical Basis of Article 2's Incorporation Strategy: A Preliminary Study, 66 U. CHг. L. Rev. 710, 715-16 (1999); see also Robert E. Scott, The Case for Formalism in Relational Contract, 94 Nw. U. L. Rev. 847, 856-58 (2000) (discussing the negative effects of incorporating standardized default terms).

68. Celia Wasserstein Fassberg, Lex Mercatoria-Hoist with Its Own Petard?, 5 CHI. J. InT'L L. 67, 81-82 (2004). 
vant to the economic perspective of international commerce; all that matters is whether it is commercial law or non-commercial law.

Economists have long been interested in lex mercatoria, both ancient and modern. Many authors have viewed the ancient lex mercatoria as prime evidence that norms created spontaneously within commerce are superior to norms created by political entities. ${ }^{69}$ The decline of the ancient lex mercatoria is traced to the decreased efficiency of communal systems and the simultaneous increase in efficiency of the state and its institutions. ${ }^{70}$ In the current world, international commerce is again thought capable of creating efficient legal norms outside the state. ${ }^{71}$

Parallel to the positive debate (and sometimes indistinguishable from it) is a normative debate on the desirability of lex mercatoria. Market liberals celebrate law merchant as a set of rules that is more efficient than state law. Since law merchant is based on party autonomy, it is more capable than centralized state law of measuring and fulfilling party preferences and thereby enhancing overall welfare. By avoiding choice of law rules, law merchant avoids the costs necessarily involved in choice of law. By ignoring potential collective or third party interests, law merchant avoids the transaction costs involved in attempts at redistribution or the interference involved with the consideration of such interests. Opponents point not only to externalities but even to efficiency losses within commerce, since the necessarily amorphous character of lex mercatoria enhances transaction costs. ${ }^{72}$

Both the empirical underpinnings and the specifically economic arguments are of limited importance here. Underlying the debate is agreement on one crucial point: whether commercial law is created in the state or in commerce is per se irrelevant to commerce itself. All that matters is the functionality of the law for commerce. This means that neither the view that all law is state law nor the view

69. See, e.g., Bruce L. Benson, The Spontaneous Evolution of Commercial Law, 55 S. Econ. J. 644, 646-51 (1989); Avner Greif, Paul Milgrom \& Barry R. Weingast, Coordination, Commitment, and Enforcement: The Case of the Merchant Guild, 102 J. Pol. Econ. 745, 745-49 (1994).

70. Avner Greif, Institutions and the Path to the Modern Economy: Lessons from the Medieval Trade (2006); Avner Greif, Institutions and Impersonal Exchange: From Communal to Individual Responsibility, 158 J. Inst. \& Theoretical Econ. 168, 201 (2002).

71. Gillian K. Hadfield, Privatizing Commercial Law, Regulation, Spring 2001, at 40, 45.

72. For economic arguments in favor of the lex mercatoria, see Dieter Schmidtchen, Territorialität des Rechts, Internationales Privatrecht und die privatautonome Regelung internationaler Sachverhalte: Grundlagen eines interdisziplinären Forschungsprogramms, 59 Rabels ZeITSCHRIFT FÜr AUSLÄNdISCHES und internationales Privatrecht 56 (1995) (summarized in English by De Ly, supra note 7, at 170). For economic arguments against the lex mercatoria, see Jürgen Basedow, Lex Mercatoria and the Private International Law of Contracts in Economic Perspective, in An Economic Analysis of Private International Law 57 (Jürgen Basedow, Toshiyuki Kono \& Giesela Rühl eds., 2006). 
that the law of international commerce exists purely outside the state makes much sense. Commerce participants will always choose between state and non-state institutions depending on which of them are more efficient, with no a priori preference for one over the other. State and non-state norms and institutions are related to each other to some extent by competition and to some extent by mutual supplementation. Similarly, it makes relatively little sense to think of lex mercatoria as an independent legal system, just as the commercial laws within states do not constitute independent legal systems. If anything, then, the globalization of the economy has created a system of global commercial law that encompasses both state and non-state norms and institutions.

What matters to commerce, and what the debate about the autonomy of lex mercatoria from the state is really about, is not the distinction between state and non-state, but rather the distinction between economy and politics. Commercial law is distinguished not from the state but from political law, especially constitutional law and regulatory law, much of which remains traditionally within the nation state.

\section{The Internal View from the Law}

In a sense, all of this could be viewed as irrelevant. What should matter, at least for the autopoiesis emphasized by systems theory, is neither the view of the state nor that of commerce but that of the law itself, the self-observation of the legal system. Moreover, if lex mercatoria is autopoietic, then it must be created neither in the state, nor in commerce, ${ }^{73}$ but within the law itself. But this is true for the law in general; it is not specific to lex mercatoria. All law, whether state law or non-state law, is "law without a state," in the sense that the legal system creates itself in separation from the political system - although, of course, state institutions like legislators and courts play an important role as recreated within this autopoietic legal system. For the same reason, however, all law is "law without international commerce," because the legal system is likewise separate from the economic system - although commerce is recreated within the legal system. It makes more sense to understand the debate over the state or non-state character as a question of system differentiation.

The main problem of lex mercatoria is not whether it is state or non-state law. The main problem is whether its structure, its internal differentiation, reflects that of the political system or that of the economic system. The global political

73. LIECKWEg, supra note 19 , at 30. 
system still represents a segmentary differentiation: it consists, primarily, of states, every one of which must perform essentially the same functions. ${ }^{74}$ The economy, by contrast, represents a functional differentiation: the boundaries that matter within the global economy are those between different sectors of the economy, not those between different states. International trade has made the boundaries between states irrelevant - if not for the economy as such, then certainly for the definition of its subsystems.

This tension between an essentially state-based political system and a transnational economy explains the tension within the law. Traditionally, the law reflected the structure of the political system: legal systems were national systems. Commercial law, so the argument would have to go, is the first part of the law which leaves behind its state-based structure and adopts instead the structure of the economic system. By contrast, since lex mercatoria is confined to international commerce, such a shift would have no direct implications for other parts of the law-constitutional law, for example — which may (or may not) remain within a state-based structure.

Whether this shift of commercial law from a state-based structure to an economy-based structure does or does not take place is an empirical question. The evidence suggests that such a shift has in fact occurred. In either case, however, this would not be a shift to a "law without a state" in a meaningful sense. As long as commercial law reflects the political system, it remains state law because the internal differentiation within the political system concerns the boundaries between states. If, by contrast, commercial law reflects the economic system, then it concerns both state and non-state norms and institutions because the internal differentiation of the economy concerns not the boundaries between state and non-state, but rather the boundaries between different sectors of the economy.

\section{The True Lex Mercatoria - Implications}

The empirical result is quite clear. Both in history and in the present, we find a law merchant in the sense of a commercial law that transcends boundaries and is in that sense transnational. However, the law that we find is not truly autonomous from the state in any meaningful sense. Rather, we observe a continuous competition and interplay between state and non-state institutions. International arbitration replicates the structures of the state; ${ }^{75}$ the state creates institutions (like

74. Niklas Luhmann, Der Staat des politischen Systems: Geschichte und Stellung in der Weltgesellschaft, in Perspektiven der Weltgesellschaft 345, 375-76 (Ulrich Beck ed., 1998).

75. For a similar point, see Zumbansen, supra note 20, at 417-18, 427-28. 
the Tuna Court) that are inspired by the advantages of arbitral tribunals. Arbitrators incorporate national norms; national lawmakers incorporate principles from the customs and informal norms of merchants. If there is an autonomous legal system of international commerce, then it transcends the divide between state and non-state law, and its autonomy is not from the state but rather from other parts of the law, many of which remain national.

That the true lex mercatoria, the existing global commercial law, encompasses state and non-state norms and institutions is so well documented now that it would hardly be worth mentioning. By contrast, the implication for our understanding of globalized law in general and lex mercatoria could be far-reaching, and here the debate over a "law without a state" still prevents us from making significant progress. Without going into further detail, I discuss some implications in order of increasing importance.

First, and least important, the finding helps us understand more clearly differences between the ancient and the new lex mercatoria. That both transcend the state is not enough to view them as similar; it suggests only that both do not follow the segmentary differentiation of the political system of the modern state, but not whether both follow the same kind of differentiation. Closer inspection reveals a decisive difference: The medieval merchant law was a status-based law for merchants, ${ }^{76}$ reflecting a stratified society that distinguished between different classes of individuals. The new new law merchant, by contrast, reflects the functional differentiation of world society; it is a law for commerce, not for merchants. ${ }^{77}$

Second, the realization of the true lex mercatoria helps reframe the debate over the character of lex mercatoria. At the moment, much of this debate is captured in the unhelpful dichotomy of state law and non-state law. Within this debate, a lex mercatoria that combines both state and non-state elements can only be explained as a hybrid. ${ }^{78}$ But the identification of hybrids typically suggests that the differentiating criteria are inadequate for the object under review. ${ }^{79}$ Indeed, the state character of traditional law and the "non-state" character of lex mercatoria are incommensurable, an incommensurability that replicates the well-known incommensurability be-

76. Kadens, supra note 32, at 44-45; see also Donahue, supra note 26, at 34.

77. Teubner, supra note 12 .

78. Richard A. Epstein, Reflections on the Historical Origins and Economic Structure of the Law Merchant, 5 CHI. J. Int'L L. 1, 19-20 (2004).

79. See Ralf Michaels, Sachzuordnung durch Kaufvertrag 44 (2002) for an example from an entirely different debate (the distinction between real and personal rights). 
tween "public" and "private" law. ${ }^{80}$ The analysis has shown that the confinement of all law to "state law" is perfectly plausible once we adopt it not as a universal position but rather as the view of the state. ${ }^{81}$ (This is congruent to the legal realist view that all law is public law. ${ }^{82}$ By contrast, the view of law merchant as "law without a state" is not plausible because "non-state" is not a sensible perspective. The relevant opposition to the perspective of the state is the perspective of commerce, and here law merchant appears not as non-state law but rather as non-political law. (This is congruent with the persistent emphasis on the private character of private law).

Third, the finding provides a new perspective on current debates on the need to "constitutionalize" the lex mercatoria. It is frequently assumed that the new private law "without a state" cannot be legitimate as long as it is based only on considerations regarding freedom of contract. Opponents of lex mercatoria use this deficiency as an argument for linking all law, including lex mercatoria, to the state and its constitution. Proponents of lex mercatoria argue that it will be necessary to reinsert constitutional values into this law. However, within a functionally differentiated legal system, this last response is not the only possibility. While it is certainly necessary to control, or at least supplement, "private" commercial law with "public" constitutional law, it is not obvious that the constitutional control over this commercial law must come from within lex mercatoria itself or must otherwise be situated outside the state. Realizing that the lex mercatoria does not constitute a global law "without" a state, that it is still connected in numerous ways with the state and its law, opens the possibility that the constitutional law of states retains a degree of complementarity to the transnational law of commerce. We know that early globalization ideas about the decline of the state were more ideologically inspired than empirically acquired — states have reacted to globalization and remain important actors. Similarly, states' laws retain control over areas that are undoubtedly globalized — the Internet provides the best example ${ }^{83}$ but states play a decisive role in international trade as well. It does not seem inconceivable that the global legal system is combined of a global commercial law that has overcome state boundaries, and a global constitutional law that has not. In

80. Luhmann, supra note 54, at 403 n.67; cf. Ralf Michaels \& Nils Jansen, Private Law Beyond the State? Europeanization, Globalization, Privatization, 54 Ам. J. Сомр. L. 843, 846-53 (2006) (discussing various distinctions between private and public law).

81. Supra, Part III.A.

82. See Michaels \& Jansen, supra note 80 , at $856-58,860$.

83. See generally Jack Goldsmith \& Tim Wu, Who Controls the Internet? Illusions of a Borderless World (2006) (discussing techniques national governments utilize to control Internet communications by enforcing their own laws). 
this view, lex mercatoria can be depoliticized precisely because it externalizes political aspects of the law to another legal subsystem, that of constitutional law, which, arguably, still reflects the political system of states.

Fourth, and finally, the realization that the true lex mercatoria transcends the distinction between state and non-state laws suggests an important path toward a more radical but ultimately more adequate understanding of globalized law. Postulating a law without a state challenges the state monopoly on the creation and adjudication of law, but it does not challenge the framework in which we think of law as related and linked to the state. A law without a state is merely the counterpart of a law within the state. Ironically, such a conception does not weaken the importance of the state for the law, but strengthens it. It changes the state from a tacit background assumption to the prime criterion with which we differentiate between kinds of law. This limits our ability to think creatively about the law in crucial ways. When we talk of law without a state, we imagine a law that reproduces the way in which we know law from the state, ${ }^{84}$ with codified norms and a hierarchical system of adjudicatory decision makers. A lex mercatoria that transcends the distinction between state and non-state laws, by contrast, should enable us truly to imagine law not only outside the state, but outside even the distinction between state and nonstate, outside the state framework altogether.

"Law without a state" may have been a necessary concept to overcome the idea that all law is state law. However, as the mere negation of that idea, it lacks constructive potential; its implications collapse into either the negation or the replication of law within the state. We should leave this behind and devote our attention to the law that transcends these boundaries and presents a more credible candidate for globalization and a functionally differentiated global legal system: law beyond the state.

84. See Michaels \& Jansen, supra note $80,886-87$. 